\title{
NOTES
}

\section{Isolation and Characterization of Alteromonas luteoviolacea Strains with Sheathed Flagella}

\author{
NORMAN J. NOVICK, ${ }^{*} \dagger$ AND MAX E. TYLER \\ Department of Microbiology and Cell Science, University of Florida, Gainesville, Florida 32611
}

\begin{abstract}
Violet-pigmented bacteria isolated from the estuarine waters of Waccasassa Bay, Fla., were found to have biochemical and physiological characteristics very similar to those of Alteromonas luteoviolacea Gauthier 1982. All isolates tested had sheathed flagella, which seem to exclude them from the genus Alteromonas Baumann et al. 1972 as presently described. We suggest altering the genus description to include strains with this characteristic.
\end{abstract}

A group of gram-negative marine bacteria which produce a violet pigment and sometimes produce a yellow pigment have been extensively studied by Gauthier $(5,6)$ and placed in the genus Alteromonas $(1,2)$ with the species name Alteromonas luteoviolacea. According to the genus description (2), all species are motile by means of polar flagella and do not possess the sheath characteristic of the flagella of other marine species belonging to the genus Vibrio. We isolated eight violet-pigmented bacteria from sediment and water column samples taken from a Florida estuary. Although these isolates were nearly identical to those described by Gauthier, all of the isolates tested exhibited a sheathed flagellum. We suggest that the description of the genus Alteromonas be amended to include bacteria with this characteristic.

The eight isolates used in this study were obtained from the estuarine environment of Waccasassa Bay, Fla. Sediment and water column samples were collected by previously described methods (Novick, M.S. thesis, University of Florida, Gainesville, 1977). The samples were diluted in half-strength artificial seawater containing (per liter of deionized water) $12 \mathrm{~g}$ of $\mathrm{NaCl}, 0.35 \mathrm{~g}$ of $\mathrm{KCl}, 2.6 \mathrm{~g}$ of $\mathrm{MgCl}_{2} \cdot 6 \mathrm{H}_{2} \mathrm{O}$ and $3.5 \mathrm{~g}$ of $\mathrm{MgSO}_{4} \cdot 7 \mathrm{H}_{2} \mathrm{O}$ and plated onto media (GP/10 medium) containing (per liter of half-strength artificial seawater) $5 \mathrm{~g}$ of gelatin (Fisher Scientific Co.), $1 \mathrm{~g}$ of Phytone (BBL Microbiology Systems), and $0.1 \mathrm{~g}$ of yeast extract (Difco Laboratories). Some isolation media also contained $10 \mathrm{~g}$ of Trypticase (BBL) per liter. The $\mathrm{pH}$ of each medium was adjusted to 7.0 to 7.2 , and $2 \%$ Bacto-Agar (Difco) was added. Deep purple colonies growing on the plates were picked and streaked for purity. The isolates were kept on GP/10 and Trypticase slants and in broth.

Unless otherwise stated, all of the biochemical and physiological tests shown in Table 1 used GP/10 medium as the basal medium. The methods used for the tests have been described previously $(3,4,7,8,11,12)$. Tests for utilization of substrates as carbon sources were carried out by using half-strength artificial seawater containing $0.1 \% \mathrm{NH}_{4} \mathrm{Cl}$ and $0.005 \mathrm{M}$ phosphate buffer ( $\mathrm{pH} 7.0$ ) as the basal medium. Filter-sterilized carbohydrates were added to final concentrations of $0.5 \%$. The ability to grow in the presence of 0 ,

\footnotetext{
* Corresponding author.

$\uparrow$ Present address: Department of Agronomy, Cornell University, Ithaca, NY 14853.
}

$1.2,2.4,3,4$, and $5 \%$ (wt/vol) $\mathrm{NaCl}$ was determined by using suitably modified GP/10 agar. The growth temperature range was determined on GP/10 medium slants which were loop inoculated. In all growth studies cultures were examined after 2, 7, and 14 days. Cells for deoxyribonucleic acid extractions were grown in GP/10 broth with heavy shaking, harvested by centrifugation, washed once in saline ethylenediaminetetraacetate, and resuspended in the same solution. Deoxyribonucleic acid was extracted by the method of Miura (9). The guanine-plus-cytosine content of the deoxyribonucleic acid was determined by buoyant density centrifugation (10). The cells used for electron microscopy were from 12- to 15 -h cultures grown on GP/10 agar plates. The cells were washed from the plates with half-strength artificial

TABLE 1. Characteristics of the Florida isolates and $A$. luteoviolacea

\begin{tabular}{|c|c|c|}
\hline Characteristic & Florida strains $^{a}$ & A. luteoviolace $a^{b}$ \\
\hline Metabolism & Respiratory & Respiratory \\
\hline Oxidase & + & + \\
\hline Catalase & All weak & - \\
\hline Nitrate reduction & - & - \\
\hline $\begin{array}{l}\text { Production of amylase, } \\
\text { gelatinase, and lipase }\end{array}$ & + & + \\
\hline \multicolumn{3}{|l|}{ Growth at: } \\
\hline $4^{\circ} \mathrm{C}$ & + & - \\
\hline $20^{\circ} \mathrm{C}$ & + & + \\
\hline $37^{\circ} \mathrm{C}$ & - & - \\
\hline \multicolumn{3}{|l|}{ Growth at salinity of: } \\
\hline Distilled water & - & - \\
\hline $20-40 \%$ & + & + \\
\hline \multicolumn{3}{|l|}{ Utilization of: } \\
\hline Glucose & + & + \\
\hline Maltose & + & + \\
\hline Mannose & + & - \\
\hline Fructose & + & - \\
\hline Galactose & - & - \\
\hline \multicolumn{3}{|l|}{ Production of: } \\
\hline Violacein & + & + \\
\hline Yellow pigment & + & + \\
\hline $\begin{array}{l}\text { Guanine-plus-cytosine } \\
\text { content (mol \%) }\end{array}$ & $41-42$ & $40-43$ \\
\hline Flagella & Polar, sheathed & Polar, unsheathed \\
\hline
\end{tabular}

a All isolates exhibited the same results.

${ }^{b}$ Data from references 2,5 , and 6 . 


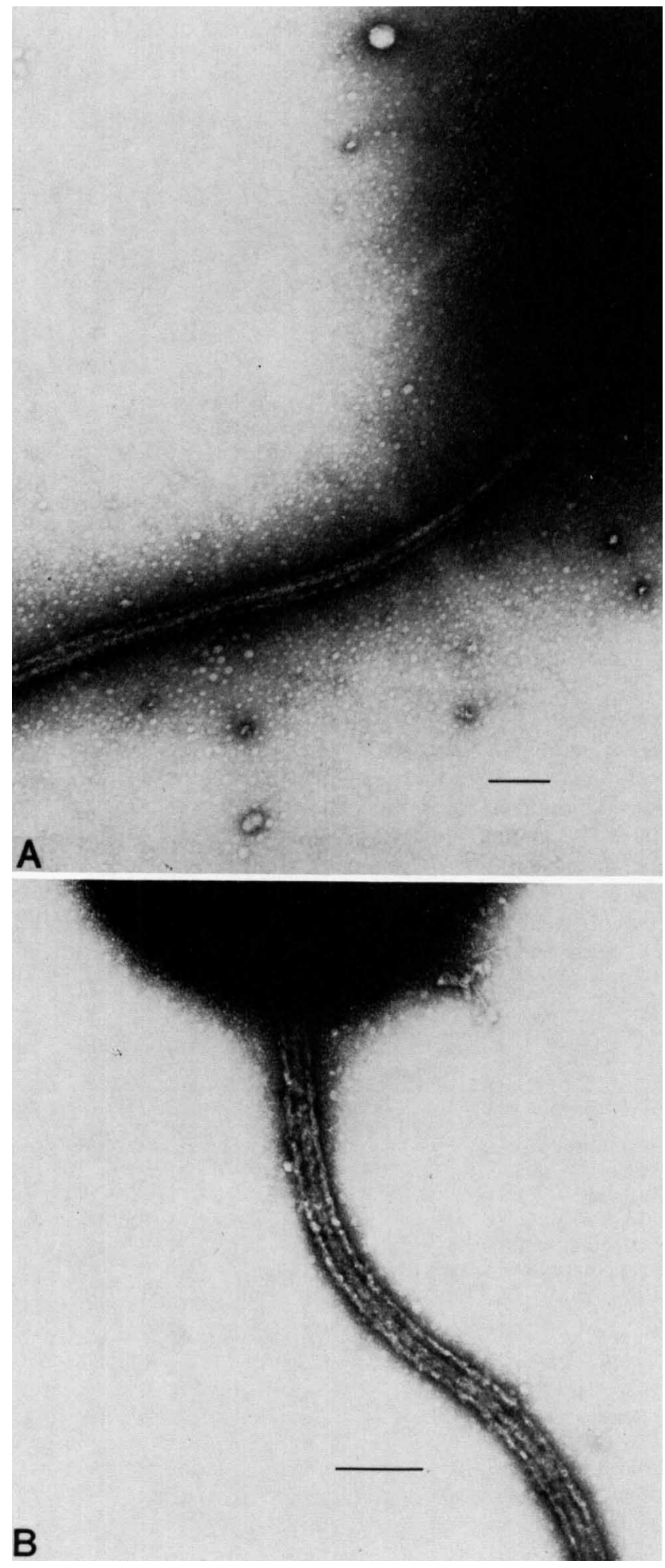

FIG. 1. Electron micrographs of negatively stained flagella from Waccasassa Bay isolates. Note the two dark lines separating the inner core from the sheath. Bar $=100 \mathrm{~nm}$.

seawater and fixed by suspending Whatman no. 1 filter paper soaked in $4 \% \mathrm{OsO}_{4}$ several centimeters above the cells in a tightly capped tube $(13$ by $100 \mathrm{~mm})$. The cells were negatively stained with $0.5 \%$ uranyl acetate, and micrographs were taken with Hitachi model IIC and IIE electron microscopes.
The characteristics of the Waccasassa Bay isolates and those of $A$. luteoviolacea are given in Table 1 . Three strains were isolated from sediment samples, and the remaining five strains were obtained from water column samples. All of the isolates were gram-negative, nonsporeforming, predominantly curved rods, which were 1.2 to $3.0 \mu \mathrm{m}$ long and 0.5 to $0.8 \mu \mathrm{m}$ wide and required a seawater base for growth. The strictly aerobic isolates had guanine-plus-cytosine contents of 41 to $42 \%$. The pigment was identified as violacein by the chemical tests of Sneath (13), and the ultraviolet and visible spectra determined with a Beckman model 25 spectrophotometer were the same as those previously published (13). A yellow pigment that was extractable with chloroform and had an adsorption peak at $432 \mathrm{~nm}$ was also noted in all isolates. All strains exhibited the autotoxic effect described by Gauthier (5).

The isolates were motile by a single polar flagellum, although multiple (2) polar flagella were observed very occasionally. With the exception of a single isolate which was not tested, all strains had a sheathed flagellum (Fig. 1). The outer diameter of the sheath ranged from 30 to $37 \mathrm{~nm}$, with a core diameter of 11.5 to $18 \mathrm{~nm}$. The interior of the flagellum was delineated by two dark lines which separated the sheath from the core.

The Florida isolates had the same guanine-plus-cytosine content, same flagellum orientation, same pigments, and many of the same biochemical and physiological characteristics as $A$. luteoviolacea. They differed from $A$. luteoviolacea in their predominantly curved-rod morphology, lack of growth factor requirement, ability to use certain carbon substrates, and ability to grow at $4^{\circ} \mathrm{C}$. They also did not exhibit the "catalase effect" described by Sneath (13) and demonstrated in A. luteoviolacea (5). Although the Florida isolates were morphologically similar to Alteromonas communis and Alteromonas undina, the lack of pigmentation in these species and differences in guanine-plus-cytosine content and other characteristics seem to exclude the strains which we studied from these two groups.

Many of the marine bacteria with sheathed flagella, including those previously placed in the genus Beneckea, are now found in the genus Vibrio (2). It is clear that many characteristics separate the Florida isolates from the genus Vibrio, most importantly their strictly respiratory metabolism. We believe that the characteristics of the Florida isolates, including their pigmentation, place them as strains of $A$. luteoviolacea, and the genus description of Alteromonas should be changed to include species with sheathed flagella.

We thank James F. Preston for technical assistance.

\section{LITERATURE CITED}

1. Baumann, L., P. Baumann, M. Mandel, and R. D. Allen. 1972. Taxonomy of aerobic marine eubacteria. J. Bacteriol. 110:402-429.

2. Baumann, P., M. J. Gauthier, and L. Baumann. 1984. Genus Alteromonas, p. 343-352. In N. R. Krieg and J. G. Holt (ed.), Bergey's manual of systematic bacteriology, vol. 1. The Williams \& Wilkins Co., Baltimore.

3. Cowan, S. T., and K. J. Steel. 1974. Manual for the identification of medical bacteria, 2nd ed. University Press, Cambridge.

4. Frazier, W. C. 1926. A method for the detection of changes in gelatin due to bacteria. J. Infect. Dis. 39:302-309.

5. Gauthier, M. J. 1976. Morphological, physiological, and biochemical characteristics of some violet-pigmented bacteria isolated from seawater. Can J. Microbiol. 22:138-149.

6. Gauthier, M. J. 1982. Validation of the name Alteromonas luteoviolacea. Int. J. Syst. Bacteriol. 32:82-86.

7. Hugh, R., and E. Leifson. 1953. The taxonomic significance of 
fermentative versus oxidative metabolism of carbohydrates by various gram-negative bacteria. J. Bacteriol. 66:24-26.

8. Kovacs, N. 1956. Identification of Pseudomonas pyocyanea by the oxidase reaction. Nature (London) 178:703

9. Miura, K. 1967. Preparation of bacterial DNA by the phenolpH9-RNases method. Methods Enzymol. 12A:543-545.

10. Preston, J. F., and D. R. Boone. 1973. Analytical determination of the buoyant density of DNA in acrylamide gels after preparative $\mathrm{CsCl}$ gradient centrifugation. FEBS Lett. 37:321-324.
11. Sierra, G. 1957. A simple method for the detection of lipolytic activity of microorganisms and some observations on the influence of the contact between cells and fatty substrates. Antonie van Leeuwenhoek J. Microbiol. Serol. 23:15-22.

12. Smith, N. R., R. E. Gordon, and F. E. Clark. 1952. Aerobic sporeforming bacteria. U.S. Dep. Agric. Agric. Monogr. 16:40-45.

13. Sneath, P. H. A. 1956. Cultural and biochemical characteristics of the genus Chromobacterium. J. Gen. Microbiol. 15:70-98. 